\title{
CREATIVITY AND ENTREPRENEURSHIP: \\ AN EXPLORATORY MULTIPLE CASE STUDY OF WHAT ENTREPRENEURS THINK
}

\begin{abstract}
Authors
Claire Allison Stammerjohan

Josh and Tasha Gardner Professor of Marketing Analytics

Thomas DeNardin*

Monica Winkel

University of Louisiana Monroe

William W. Stammerjohan

Harold J. Smolinski Eminent Scholar

Chair - Accounting

Louisiana Tech University

*Corresponding Author:

Thomas DeNardin

144 Hemphill Hall

University of Louisiana Monroe

700 University Avenue

Monroe, LA 71209

(318) 342-1156

denardin@ulm.edu

Abstract

The purpose of this exploratory, quantitative and qualitative case study (Yin 1994) is to examine the importance of creativity in entrepreneurship. Is it creativity that leads to entrepreneurial success, or are there factors of entrepreneurial creativity, such as "opportunity recognition," "programmatic implementation," and "building networks," which comprise creativity? Or perhaps creativity stands alone and is separate from the three factors? A review of selected literature on the relationship between creativity and entrepreneurship suggests that creativity is in part pre-cognitive, as well as cognitive processing as described in much of the entrepreneurial literature. This suggests that the above described factors may not be easily identifiable as creativity at all, but may in fact be equally or more important to entrepreneurship than creativity itself. Our findings are consistent with the latter idea, suggesting that even if entrepreneurial activities should theoretically be considered a creative output, entrepreneurs in our study don't see it that way. Instead they seem to see creativity as separate from those entrepreneurial activities: opportunity recognition, programmatic implementation, and building networks.
\end{abstract}

Keywords: Creativity; Entrepreneurship; Performances; Relationships

Full Citation:

DeNardin, T., Gardner, J., Gardner, T., Stammerjohan, C.A., Stammerjohan, W.W., Winkel, M. (2019). Creativity and Entrepreneurship: An Exploratory Multiple Case Study of What Entrepreneurs Think. Small Business Institute ${ }^{\circledR}$ Journal. Vol. 19, No.1, pp. $18-38$ 



\section{Introduction}

There is no shortage of literature on the subject of creativity, innovation, and entrepreneurship; however, this literature contains many conflicting views. Stephenson and Jarillo (1990) point out that some authors feel that the terms may be used interchangeably (e.g. Fillis \& Rentschler 2005). Others seem to suggest that although different, they are inextricably intertwined (Bruyat \& Julien 2005). Still others seem to feel that creativity, innovation, and entrepreneurship are fundamentally differing constructs (Amabile 1996; Dyer 2008; Phan, Zhou, \& Abrahamson 2010) perhaps describing different parts of the entrepreneurial process. In any case there seems to be agreement that entrepreneurship is an important economic driver that should be studied and encouraged (e.g. Lumpkin \& Dess 1996; Phan, Zhou, \& Abrahamson 2010; Westlund 2011; Zhang 2014) and that creativity is somehow a contributor (e,g., Schmidt, Soper, \& Bernaciac 2013; Sooy 2011; Ward 2004). Barrett, Balloun and Weinstein (2005) suggest that organizations are, and need to be more creative, and entrepreneurial in their decision making today, finding a significant correlation between creative climate and entrepreneurial activity, organizational flexibility, and organizational performance. Because of its suggested and found importance to entreprenurship, we asked entrepreneurs how they see creativity fitting into their entrepreneurial activities. To provide freedom to express their true opinion of creativity, we employed an exploratory, qualitative method of analysis using both open-ended questions for text analysis, and closed-ended questions for descriptive analysis.

\section{Definitions}

Stevenson and Jarillo (1990) suggest that entrepreneurship involves pursuing "opportunities without regard to the resources they currently control." While some other authors equate entrepreneurship with investment in new revenue streams (Bratnicka 2014), it may be more simply defined as bringing a new business (revenue stream) into being (Westlund 2011; Anderson 2000; Lumpkin \& Dess 1996). While this is often considered to be a creative undertaking, the establishment of a new franchise suggests the possibility that entrepreneurship can be programmatic, or a matter of implementation, rather than creative. Innovation can be distinguished from entrepreneurship: the key to entrepreneurship is the bringing of a new revenue stream online, while innovation is acting on new ideas and may involve any business function. Amabile (1996) further defines Entrepreneurial Creativity as using novel and useful ideas to bring a new business (revenue stream) into being, noting that these creative ideas might be about the product or service (core benefit), revenue source, distribution method, communications, financing, market identification, etc. In addition, it is worth noting that, from this perspective, it is the "programmatic" implementation of creative ideas that makes it entrepreneurial.

\section{Literature Review}

Like early creativity literature, much of the early entrepreneurship literature is focused on the traits of the entrepreneur, specifically those traits that predispose persons to entrepreneurship (e.g. Carland, Hoy, Boulton, \& Carland 1984; Berglund \& Wennberg 2006). Several of these traits are also conducive to creativity: "Risk-taking behaviour, being able to control rather than be controlled, being independent, not being afraid to fail 
and having the perseverance to succeed all feed into creative output" (Fillis \& McAuley 2000). Creativity is identified as a competitive strength (Kao 1989), a key competency of entrepreneurs (Carson et al. 1995) and an entrepreneurial attribute (Bridge et al. 1998; Hamidi et al. 2008). On the other hand, Carson (1995) contends that the creativity of entrepreneurs is a function not only of their personality but also of the general situational characteristics of new businesses. Carson describes this creativity, found not so much in product development but throughout day-to-day business decisions in the organization, as reactive, conservative, short-term focused--in other words "incremental." Recently, Dayan, Zacca, and Di Benedetto (2013) used an attitudinal/behavioral model to show that access to resources, entrepreneurial alertness, expertise, and intrinsic motivation are antecedent to Entrepeneurial Creativity. Rosly, Junid, Lajin, and Rahim (2015) found that Creativity is predictive of "Technopreneurship Intention."

Like the extensive creativity literature about process and activities, another body in the literature has focused on entrepreneurial processes or activities (Gartner 1989, Davidsson 2006; Matthews 2007; Morris et al. 2013; Mueller 2012). These activities usually include identifying entrepreneurial opportunity (Alvarez, Young \& Wolley, 2011, Hansen, Lumpkin and Hills, 2011; Venkatraman, Sarasvathy, Dew, \& Forster 2012; Wook \& McKinley 2010), being proactive, risk-taking (Bridge et al 1998; Covin \& Slevin 1991), and product and technological innovation (e.g. Covin \& Slevin 1986).

Dimensions of firm entrepreneurial orientation from Miller, Covin and Slevin's (1989) scale include marketing of new products/services (innovation), aggressively competing with other firms (proactiveness), and taking risks for high rewards. Lumpkin and Dess (1996) included experimenting with new technologies. Hughes and Morgan (2007) separates proactiveness (being first + identifying opportunities) from aggressive competitiveness, and adds employee autonomy (Covin \& Wales 2011). Westlund (2011) sums up these activities as discovering, evaluating, collecting resources to implement, and exploitation of opportunities. Networking, with customers or others, is considered another important entrepreneurial activity (Shalley \& Perry-Smith 2008). Hackley and Mumby-Croft (1998) make the point that creativity drives entrepreneurial success through marketing.

Fillis and McAuley (2000) develop a model of "Creativity at the Marketing/Entrepreneurship Interface" with the entrepreneurial firm and marketer being acted upon by marketing competencies and entrepreneurial competencies producing the creative individual, who is influenced by social and other environmental influences as well as personal cognitive skills and personality traits, to produce creative strategy. Bruyat and Julien (2005) describe an entrepreneur effecting change in an environment and being affected by that change, acknowledging that there is no entrepreneurship without the entrepreneur, and that the new business is both the product and part of the environment for the entrepreneur. They then suggest that this makes the field of research the "black box" of how entrepreneurs create value and how new venture creation affects them. Alternatively, Anderson and Starnawaska (2008) suggest that a positivist approach to entrepreneurship research may not be appropriate, and argue for a constructivist view of entrepreneurship: it is what people think it is. These views encourage us to take a more 
holistic view of entrepreneurship, however a number of authors have opted for researching a smaller piece of the puzzle.

Like the entrepreneurship literature, in the creativity literature, the discussion of level of analysis is critical: person, product, organization. Batey (2012) provided a three dimensional framework for the study of creativity, reminding us that one must consider whether one is researching the person, team, organization or culture (dimension 1); the trait, process, environment, or product (dimension 2); and measuring it objectively, with self-ratings, or other ratings (dimension 3). These decisions seem appropriate to entrepreneurship research as well. In the entrepreneurship literature there is a distinction between the entrepreneurial work of the individual and "corporate entrepreneurship," or bringing in new lines of business, but the distinction between the individual and the company is less clear for small firms.

\section{State of Art of Research on the Creativity- Entrepreneurship-Performance Relationships}

As business persons, we are interested in the relationships whether creativity "causes" either entrepreneurship or firm performance. Fortunately, there is a rich literature linking creativity, entrepreneurship, and performance. Barrett, Balloun, and Weinstein (2005) shows a significant correlation between creative climate and entrepreneurial orientation. Ward (2004) argues that the novelty/familiarity balance is key to the success of new ideas, and discusses ways in which cognitive models can help direct this balance. In a longitudinal study, Ford, Sharfman and Dean (2008) find that creativity of strategic decisions improves performance between 5-10\% using pre-established targets for success. These authors feel that creative strategic decisions result from a dynamic and competitive environment, and that creative decision processes are negatively correlated with creativity of decisions. We explain this seemingly contrary finding by speculating that since these decisions were the result of processes, they don't seem creative. Alternatively, perhaps in retrospect, the decisions seem only logical. Still, these contrary findings suggest more research is necessary for resolution of these questions.

Heunks (1998) develops and tests a model of the relationship of creativity and innovation on performance. Heunks does not find evidence supporting benefits of creativity in general, finding it only related to increases in product [innovation] in all firms, and product innovation in older firms. Heunks looks for beneficial effects on growth, productivity, product or process innovation, marketing innovation, or R\&D innovation. These results seem somewhat counter-intuitive. Recently, some research on the relationship between creativity, entrepreneurship, and performance has tended to include an action-oriented link or mediating variable, such as Amabile's entrepreneurship behavior, entrepreneurial orientation, (Bratnicka \& Bratnicki 2013), or action orientation (Weinzimmer, Michel, \& Franczak 2011). This reflects current thinking that innovation and/or entrepreneurship are strategic directions of the firm, and reflect the firm's ability to implement creative ideas. 
Another stream of literature has tended to focus on the effects of dimensions of creativity on performance, or on entrepreneurial activities. For example, Gielnik, Frese, Graf, and Kampschulte (in press) found divergent thinking had a positive indirect effect on venture growth through generation of "original business." Divergent thinking produces many and original ideas, but is not directly related to venture growth. A positive relationship between original business ideas and venture growth means that the originality of the ideas generated is important to business growth, however that seems to be contingent on dynamism and competitiveness of environment (Nerkar \& Shane 2003; Zahra \& Bogner 2000). The number of business ideas is not related to growth. More diverse information positively moderated the effect of divergent thinking regarding business idea generation. (Gielnik, Frese, Graf, \& Kampschulte, in press). Wolf and Meig (2010) find the ability to switch between divergent and convergent thinking aided self-employed inventors.

Another important aspect of the creativity and entrepreneurship relationship is the entrepreneur's networking activities (Bruderl \& Preisendorfer 1998; Molina-Morales \& Mas-Verdu 2008; North \& Smallbone 2000; Watson 2007; Witt 2004). A complete review of this literature is beyond the scope of this paper. However, it is generally accepted that an entrepreneur's network provides multiple types of resources for entrepreneurial creativity or innovation (Tomlinson 2010). These networks can provide access to financial resources, customers or suppliers, technology, or from a cognitive processing perspective, diverse information (Granovetter 1973). Absorptive capacity is organizational recognition and commercial use of the value of new information (Ahlin, Drnovsek \& Hisrich 2013; Licuanan, Dailey, \& Mumford 2007). Napier, Vu, and Vuong, (2012) suggest that culture, creativity, and business development stage are generally linked, and that creativity may be most critical in the "entrepreneurial stage" as firms are developing their business model, mission, and long and short term strategies.

\section{Opportunity Recognition}

Perhaps one of the most researched aspects of entrepreneurship is opportunity recognition. Some studies proposed that creativity is antecedent to opportunity recognition; however, in a qualitative study, Ardichvili and Cardozo (2000) did not find entrepreneur creativity antecedent to successful opportunity identification. Others have modeled opportunity recognition as an inherently creative process similar to Cskiszentmihalyi's (1996) creativity model (Hills, Schrader \& Lumpkin 1999; Lumpkin, et al 2004). Hansen, Lumpkin and Hills (2011) tested this model using structural equation modeling. However, their confirmatory factor analysis finds only incubation and elaboration activities significantly related to an endogenous creativity variable. Corbett (2005) maps experiential learning onto this model, and suggests that the opportunity recognition is a transformative learning experience. Dyer, Gregersen, and Christensen (2008) use qualitative research to develop an attitudinal/behavioral model of opportunity development. These authors see four behaviors--questioning, observing, experimenting, and networking--as foundational to associational thinking and opportunity recognition.

Dimov (2007b) sees opportunity finding not as a flash of creative insight, but as a "socially complex longitudinal phenomenon" including situational factors, e.g.--"the entrepreneurial context of action under uncertainty"--as well as process and individual or 
organizational factors, mentioning a four "I" framework for organizational learning: intuiting, interpreting, integrating, institutionalizing (Crossan Lane \& White 1999). This model provides several interesting insights. Overall, it provides a link from individual learning to organizational learning. In addition, it suggests that intuiting is preconscious. Finally, it also suggests that the individual and firm networks are important in the organizational learning that takes place as opportunity recognition. Dimov (2007a) finds support for the idea that a dichotomous match between entrepreneur learning style and opportunity type will act as an on/off switch (a positive moderator) for the relationship between domain specific knowledge and opportunity recognition.

The literature seems to show that there is a wide variety of ideas and theories connecting creativity and entrepreneurship, but little consensus. In order to try to bring some harmony to this discussion, we asked entrepreneurs how they see it. Using Amabile's (1993) entrepreneurial creativity as a starting point, we developed a model suggesting that creativity is the foundation of three activities mentioned in the literature: opportunity recognition, programmatic implementation, and network building. Alternatively, perhaps our entrepreneurs will see creativity as a separate concept that contributes to entrepreneurship performance. These alternate models are shown below.

Figure 1: Competing models of the creativity/entrepreneurial performance relationship.
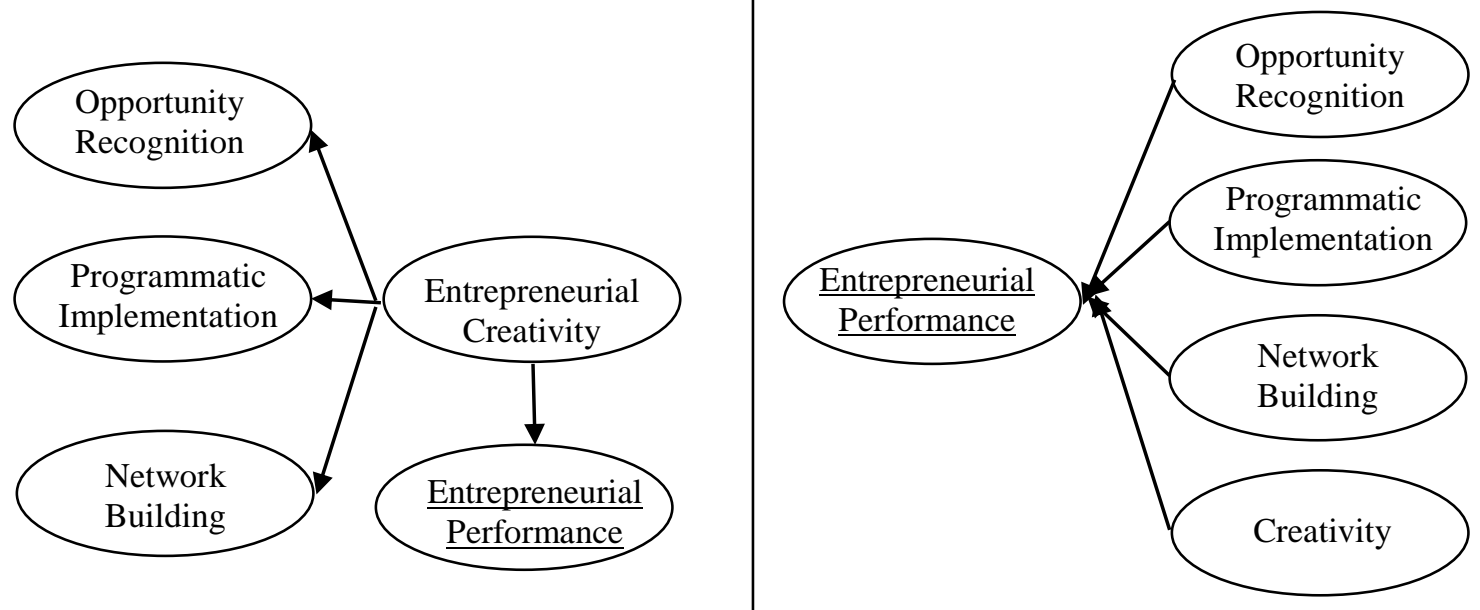

\section{Method}

Because our goal was to compare the attitudes and belief of entrepreneurs to the findings of the current literature, we conducted an exploratory, qualitative, and quantitative, multiple case study. According to Yin (1994), case study research is appropriate to describe the lived experience of entrepreneurship, a complex social phenomenon. Yin (1994) and Eisenhardt (1991) also suggest that multiple cases are appropriate when "a replication logic" is proposed to be evidence for generalizations from the cases. Thus, our method was a multiple case study, exploratory survey of the attitudes of entrepreneurs. Sampling was purposive in that students were to select, for data collection, a known entrepreneur who had started their business and employed 100 employees or less. Our 
primary research question is derived from the literature review as shown by the competing models above: Do entrepreneurs see creativity as a critical, fundamental aspect of entrepreneurship (sum of the parts), or do they see it as a separate entity that may or may not contribute to entrepreneurial performance?

The case study method allows for both quantitative and qualitative methods (Eisenhardt 1989, Yazan 2015) so both coded, closed-ended questions and open-ended questions were used for quantitative and qualitative descriptive analysis. These tabular analyses are presented in the results section along with the qualitative interpretation of respondent statements.

Thirty-two entrepreneurs that own local, regional, national, or international small businesses were interviewed by students from a senior and graduate entrepreneurship class. Qualitative studies often use relatively small sample sizes due to the larger volume of data collected from each respondent and because the goal is understanding rather than generalization or formal hypothesis testing (Ritchie, Lewis, and Elam 2003). Qualitative coding was carried out by multiple authors and discrepancies were resolved through discussion. Three of the authors have entrepreneurial experience, and conclusions were discussed in the same manner as the original textual coding.

\section{Results}

\section{Sample Description}

The average age of the businesses was almost sixteen years, with a range of 1-60 employees. Eighty percent (26) of our respondent companies were at least 6 years old, and of those, 38.5\% had been in business over 20 years. Most entrepreneurs (78.1\%) took at least some college courses, while $40.6 \%$ had a college degree. The majority of businesses $(81.2 \%)$ that were interviewed were local or regional in scope. Nearly half the sample had 5 or fewer employees $(43.8 \%)$, the other $56.2 \%$ included firms with fewer than 50 employees $(40.6 \%)$ and over 50 employees (15.6\%). The questionnaire included questions as to what the entrepreneurs believed were factors to becoming a successful entrepreneur.

\section{What Entrepreneurs think about Entrepreneurship and Creativity}

To examine what entrepreneurs spend most of their time on after the businesses is up and running, we provided three options (necessities, solutions, and new products) and asked the entrepreneurs to put a percentage, totaling one hundred percent, next to the three options. There was a broad range of time spent dealing with the day-to-day necessities of running their businesses. Our entrepreneurs reported spending $25 \%$ of their time on solutions, while only $20 \%$ on new products. The $55 \%$ allocated to necessities in this study is only somewhat behind the $65-75 \%$ of time allocated to "exploitation" found by Mueller, Volery, and von Siemens (MVV 2012). There may be some overlap between our "solutions" category of activities, which we saw as day-to-day unstructured problem solving, and MVV's exploitation category. 
Table 1: Demographics of the 32 Entrepreneurs

\begin{tabular}{|c|c|}
\hline Business Type & $\underline{\mathrm{N}}$ \\
\hline Service & 28 \\
\hline Merchant & 4 \\
\hline Scope of Sales & $\underline{\mathrm{N}}$ \\
\hline Locally & 14 \\
\hline Regionally & 12 \\
\hline Nationally & 4 \\
\hline Age of Business (Years) & $\underline{\mathrm{N}}$ \\
\hline $1-5$ & 6 \\
\hline $6-10$ & 13 \\
\hline $11-20$ & 3 \\
\hline $21-50$ & 9 \\
\hline $51+$ & 1 \\
\hline Number of Employees & $\underline{\mathrm{N}}$ \\
\hline $0-5$ & 14 \\
\hline $6-10$ & 4 \\
\hline $11-25$ & 7 \\
\hline $26-50$ & 2 \\
\hline Above 50 & 5 \\
\hline Years of Education & $\underline{\mathrm{N}}$ \\
\hline Up to $12^{\text {th }}$ grade & 3 \\
\hline High School Diploma & 4 \\
\hline Some College & 11 \\
\hline Associates Degree & 0 \\
\hline Bachelor's Degree & 5 \\
\hline Master's Degree & 6 \\
\hline Doctorate Degree & 1 \\
\hline Professional Degree & 2 \\
\hline
\end{tabular}

In the same MVV study entrepreneurs in the start-up phase spent $21 \%$ of their time on product development and growth-stage entrepreneurs spent only $9 \%$ of their time on product development as compared with our $20 \%$. Since most of our sample would seem to have been past the start-up stage, the difference in time on product development deserves consideration. There are at least two possible reasons for this difference. One possible explanation is that our small business entrepreneurs simply define product development differently. They may be thinking less of radical new products, and more of steady improvement of their current product portfolio. Another alternative is that since 
many are microbusinesses, many of these entrepreneurs have not become managers who are more dissociated from the operational side of the business, and consider refinement of their product simply the practice of their craft. In any case, this is a difference that bears further investigation.

The entrepreneurs interviewed were asked an open-ended question as to how the idea came to mind to start their business. Four themes accounted for about $56.2 \%$ of the responses: Of the responding entrepreneurs, $28.1 \%$ saw an opportunity, $9.4 \%$ had the knowledge and skills, $18.8 \%$ wanted to work for themselves, while $15.6 \%$ joined or created a family business. Some answers were: "I already possessed the skills and I wanted to work for myself," "I was in the right place at the right time and seized the opportunity," "This was a family business that I bought into. I grew up in this business." These reasons are consistent with reasons in the literature (e.g. Orhan and Scott 2000; Sahbbir and Di Gregorio 1996). Other entrepreneurs were less typical, as shown in the table below:

Table 2: Atypical Business Origins

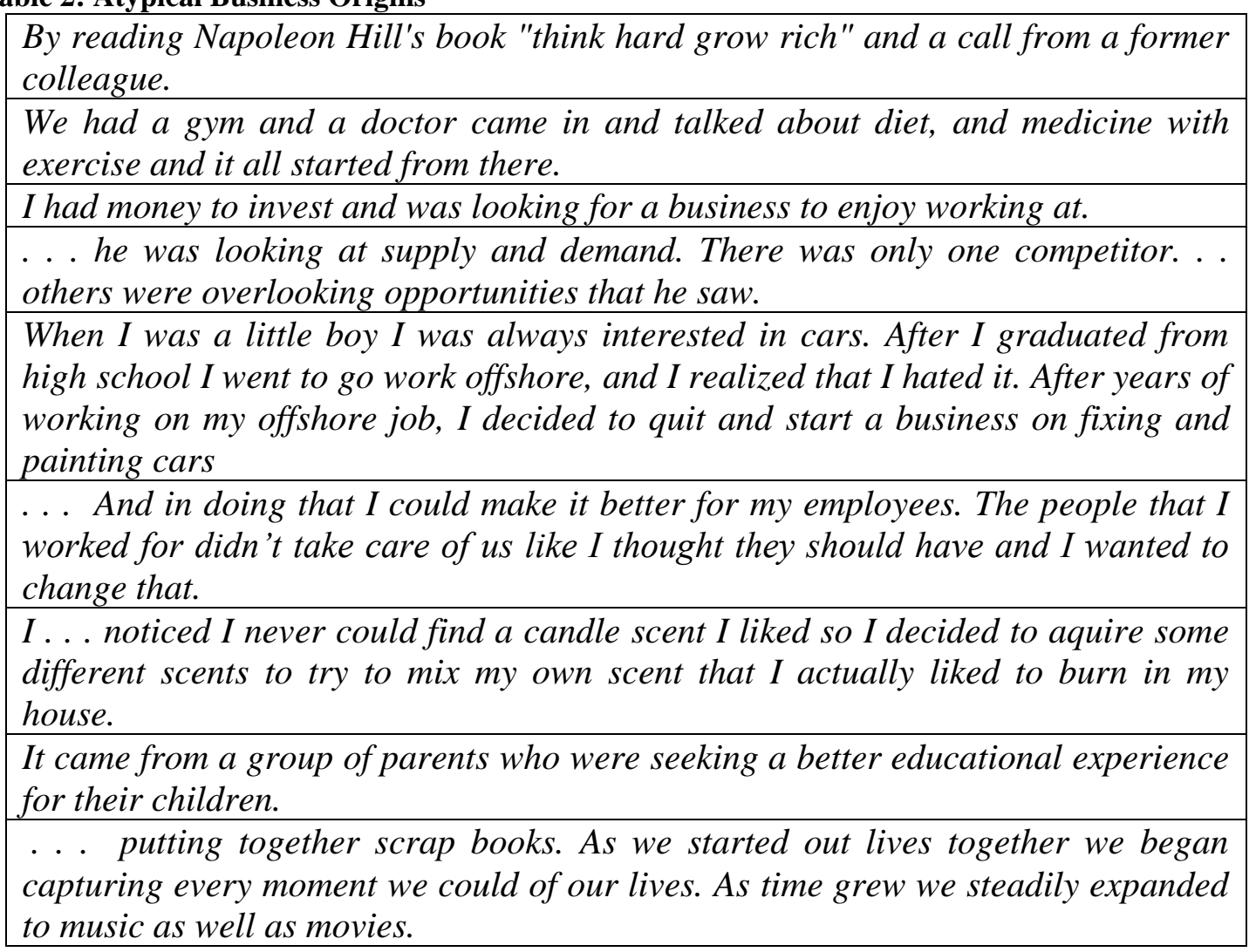

It seems the inspiration for entrepreneurship can come from within the entrepreneur, or from that external, "recognized opportunity."

In another question used in the questionnaire, we used Thomas Edison's famous quote, "Invention is 99\% Perspiration and 1\% inspiration" and asked the entrepreneurs how much they agreed with Edison's statement. We asked the question if Invention is 99\% 
Perspiration and $1 \%$ Inspiration? More than $56 \%$ agreed while only $28 \%$ disagreed. The question of why may be an area that deserves more study.

Table 3: Responses given by the entrepreneurs about Invention/Entrepreneurship is 99\% Perspiration and 1\% Inspiration

\begin{tabular}{lr}
\hline Invention is 99\% Perspiration & \\
\cline { 1 - 2 } and 1\% Inspiration & \\
Absolutely True & $9.4 \%$ \\
Strongly Agree & $15.6 \%$ \\
Agree & $31.2 \%$ \\
Neither Agree nor disagree & $15.6 \%$ \\
Disagree & $28.1 \%$ \\
& \\
Entrepreneurship is 99\% & $\underline{\mathrm{N}}$ \\
Perspiration and 1\% Inspiration & \\
Absolutely True & $9.4 \%$ \\
Strongly Agree & $25 \%$ \\
Agree & $25 \%$ \\
Neither Agree nor Disagree & $15.6 \%$ \\
Disagree & $25 \%$ \\
\hline
\end{tabular}

The interesting question was now whether these entrepreneurs felt the same way about entrepreneurship. Our findings show that over 59\% agreed on this statement while only $25 \%$ disagreed. One can see that majority of the entrepreneurs believe that it is easy to come up with an idea, but it is the actual putting in place (implementation-programming) of one's idea that makes a person a real entrepreneur. This is consistent with the literature that defines entrepreneurship as a set of business activities involved with creating a new revenue stream, rather than as a product of creativity (Bratnicka 2014; Stephenson and Jarillo 1990). In fact, Davidsson (2006) divides entrepreneurship activities into two stages: opportunity recognition and opportunity exploitation. On the other hand, one might argue that there is opportunity for creative thought at both stages. The correlation between the invention and entrepreneurship responses in Table 3 is 0.32 , with a p-value of 0.038 .

One other question that we asked the entrepreneurs is what they believe the most important factor is to be a successful entrepreneur. We got slightly different percentages of answers than what we had expected. As mentioned before, creativity is believed by some to be the number one player in being innovative and becoming an entrepreneur. The options that the entrepreneurs could choose from were creativity, opportunity recognition, building networks, and programmatic implementation. 
A Delphi study as preliminary to Morris et al. (2013) showed networking as an important competency of entrepreneurship. Likewise, according to our results, $15.6 \%$ of the entrepreneurs believe that building networks is the most important factor to success. Some answers were: "People help opportunities come your way," and "Networking is how we started our business. Swap meets and tradeshows are where we began. Word of mouth is very powerful. We met a Wal-Mart manager at one of these shows, and that is why our business took off the way it did." Perry-Smith and Mannucci (2015) go on to suggest that the study of social networks in entrepreneurship is important for both the opportunity recognition and implementation stages of entrepreneurship, arguing that "social resources have important signaling functions for investors," and that other people in the network (strong and weak ties) can provide not only information, but changes in the entrepreneur's cognitive structure that can result in greater entrepreneurial creativity.

According to Ahlin et al. (2014) and Amabile (1996), creativity, by itself is a starting point for innovation, but it is not sufficient for entrepreneurship. Perhaps this is why, according to our results, only $12.5 \%$ of the entrepreneurs said that creativity is the most important factor to success. Some of the examples that entrepreneurs gave were "To be an entrepreneur requires the ability to go after opportunities in the business world, regardless of the hardships and financial requirements. Anyone can take money and make money, but to do so with only the hope of being able to make it is the true heart of an entrepreneur," and "Without execution of the business plan consistently over a long period of time, opportunities to be creative and to expand the business are compromised or lost all together. . execution must always be the [top] priority."

The same number, another $12.5 \%$, said that "rogrammatic" (implementation, or Davidsson's 2006 "opportunity exploitation") is the most important factor to success. Some answers included: "There are many great ideas/opportunities. It is very important to pick one that you can execute. The old saying that an ' $A$ ' execution of a ' $C$ ' idea is better than a ' $\mathrm{C}$ ' execution of an ' $\mathrm{A}$ ' idea. With over 120 employees, it is very important to have everyone on the same page executing the processes that are in place. Otherwise, it is chaos. It really boils down to doing the basic stuff brilliantly. Another person who selected programmatic said, "Implementing the creative idea is really more entrepreneurial than being creative." Given the finding (Pretorius et al. 2005) that some entrepreneurs think more highly of their own creativity or their firm's innovativeness than they do of their firm's implementation orientation (ability to overcome barriers or implement their decisions), our respondents in this group may have a point.

The majority of entrepreneurs, 59.4\%, said that Opportunity Recognition is the most important factor to succeed as an entrepreneur. As some entrepreneurs stated: "It's the ability to find the gap that needs to be filled to improve the current product or service," or "I have the ability to understand what people need and fill those needs," while another said: "It's the ability to recognize changes in trends that affect your business."

Although all these four factors seem to play a role in the lives of real entrepreneurs, opportunity recognition is seen as the most important key to success. Mentioned by 
$59.4 \%$ of entrepreneurs as the most critical issue in entrepreneurship, opportunity recognition is certainly number one in the literature as well.

\section{What It's like to be an Entrepreneur}

We asked what it's like to be an entrepreneur. One person said, "Either you have it or you don't." Another said, "You need to have guts and be able to take risks. A strong work ethic is required in order to succeed as an entrepreneur. You need passion to press on in your area of interest. You must be patient to watch your firm grow," which covered a lot of topics. Three coauthors have entrepreneurial experience, and we expected that entrepreneurs would mention a couple major challenges: keeping the business afloat and taking care of employees before yourself. Several respondents did mention these a priori themes. Some examples included,

How to manage cash flow, how to budget in slow business, extreme self control and discipline

It's hard work and perseverance. Proper planning and never giving up.

You must have a positive cash flow from the beginning. One must have a business background or education. A mentor is highly recommended and resourceful.

You have to be willing to pay others while you may or may not get paid. When everything is going great, you are doing great. When everything isn't, you aren't.

The lives of every employee is affected by the success and failure of my business. I don't take the responsibility lightly. Also, every day brings new worries of risk. There never really is a stress-free time. There is always a mix of reward and worry.

It's important to treat your employees well and have them work their best so that your company can stand out and make customers want to come to you."

The most common emergent theme was one of "hard work" and/or how challenging the job is.

It's hard work and perseverance. Proper planning and never giving up.

Lonely at the top. Who do you ask for help? . . . lose sleep over what's going to happen tomorrow.

Late nights, early mornings. Mental stress. Emotional stress.

Work really hard, state your new ideas, and be open-minded and willing to learn from peers and others.

Long hours and dedication is what helps to build a business. You have to be available when the customer needs you. 
It takes a lot of hard work and effort to be successful. Everybody wants to take the elevator to the top instead of putting the hard work and effort into the necessary steps needed to get here.

I don't believe we have enough time. Basically take everything you think it takes to be an entrepreneur and multiply it by 10.

Waking up early morning knowing that there are going to be failures throughout the day, but learn from them, grow from them and never give up. It is the most challenging but most rewarding. If it was blue skies and rainbows, everybody would do it.

“. . .Nothing comes easy. Whether you have been an entrepreneur for years or you are just starting there will be obstacles you have to overcome on a [daily] basis. And an entrepreneur must be very strong mentally, physically, and emotionally. . ."

... there are no free rides.

[knowing] that you may make mistakes and the business may not be as great as it seems when you plan, but never give up.

It's not an easy task, it's going to take more than 40 hours per week to become better and ultimately improve your craft at a high level.

Another common theme was risk.

To be an entrepreneur, you need to be willing to risk everything to gain everything or absolutely nothing at all.

An entrepreneur has to be driven, and you can't be scared to take risks. . You have to learn everything all over.

Being an entrepreneur is not just a job. It's an adventure where you have to take risks, you have to be mentally strong, and most of all you need confidence. We have to pay attention to every choice because there is nobody to check behind you and tell you what to do.

You have to be able to understand your risk and cost with starting your own business and work to minimize these from the start.

A bit of experience that the authors felt they had experienced was that the entrepreneur bears all the responsibility.

If you don't like how things are going, look in the mirror. My success or failure depends on my decisions. The only people who affect my success or failure are the people I hire.

We have to pay attention to every choice because there is nobody to check behind you and tell you what to do.

To be an entrepreneur you need to be independent. Basically, if you, as the entrepreneur, 
don't make it happen, it will not be done.

The best part about being an entrepreneur is that you're your own boss. You call the shots. The success of your business (or failure ...) completely depends on the decisions you make. How far or big your business goes is completely up to you. The possibilities are endless.

Finally, finding a business to love was mentioned enough to be considered a theme.

I wouldn't suggest starting up any business out there. Wait until a certain idea touches your heart so that you will see the passion that a lot of entrepreneurs burn with everyday. You must love what you do, don't worry about the success.

You have to feel passionate about what you do. This was an opportunity to provide a living doing what he enjoyed.

Find a business you like.

\section{Discussion}

The results led us to believe that many entrepreneurs do not believe creativity is the key player in becoming a successful entrepreneur. When asked what it was like to be an entrepreneur, creative appeared only twice. One entrepreneur noted that

... the art of dance is a creative process. Dance can tell a story or even paint a picture for some individuals. Creativity is most important to succeed because being creative cannot only make your business stand out but it can also keep participants interested in your company.

Our dance entreprenuer's statement suggests that entrepreneurship may be subject to domain specificity issues in the same way that creativity is. Some scholars believe that before you can talk about the creativity of anything, you must first define the domain in which you are operating (e.g. Baer 1998). Creative scholars debated domain specificity at length (Amabile 1983; Amabile 1996a; Amabile 1996b; Baer 1996; Baer 1998; Baer 2012). Perhaps it is easier to recognize creativity in an industry that is known for its exercise, but more difficult to recognize across diverse industries. Thus another entrepreneur saw creativity resulting from the need to overcome obstacles along the way.

As an entrepreneur you have to be creative. It's almost impossible to own a business without having new ideas. More than likely when you first decide to work in your own business, you're not going to have all the resources that you need, so as an entrepreneur you have to learn how to think out[side] the box to get your business started. It is not going to be easy, and it might be the hardest thing that you have done in your life.

These two statements may pretty well encapsulate the duality of creativity in entrepreneurship. For the first entrepreneur, her business is based on a creative endeavor. 
She is all in with creativity. Creativity is required in her product as well as other aspects of running her business. For the second entrepreneur, it is the demands of the business that require creativity - this may be more similar to the entrepreneurial creativity described by Amabile (1996b). It may be that the study of creativity is like the study of entrepreneurship, or even the study of business: The generalities are at a very abstract level. Entrepreneurs are most often concerned with how to make payroll this week.

When the question was asked what entrepreneurs focus most of their time on when their business is up and running, it was focusing on day to day necessities of running their business, more similar to the implementation or "opportunity exploitation" concepts. Focusing on new products or services got the lowest percentage, and, therefore, we can also conclude that creativity or innovation is not the main focus that drives most entrepreneurs' day to day activities. This is also evidenced by entrepreneurs' support for the idea that entrepreneurship is $99 \%$ perspiration.

There are at least two possible explanations for our results. The first is that for entrepreneurs, creativity may operate at a precognitive level, and the entrepreneur doesn't even think of themselves in that light. To them, many of the things they do seem ordinary, or simply a reaction to the demands of their business. However, as mentioned by Carson et al. (1995), entrepreneurial creativity may in fact be quite incremental and reactive, rather than radical and novel. Entrepreneurs who are busy running their business may not even realize the myriad creative (unstructured) problem-solving opportunities afforded by running a business. They are simply doing business. An equally likely possibility is that if entrepreneurship is defined as a set of activities (e.g. Bratnicka 2014; Mueller et al. 2012), entrepreneurs focus on those activities rather than on the decisionmaking process (latent constructs) behind the activities (as mentioned in the paragraph above). Thus, the activities take precedence over the more abstract idea of creativity.

\section{Directions for future research and Conclusion}

Entrepreneurial action focus suggests future researchers of the link between creativity and entrepreneurial performance will need to agree on a set of activities that can represent creative decisions to use as a measure for entrepreneurial creativity. A start has been made with the creative opportunity recognition scale by Hansen, Lumpkin, and Hills (2011); Others who have created scales for opportunity recognition behaviors include Dyer, Gregersen, and Christensen (2008) and Gregoire, Shepherd, and Lambert (2010). However, Hansen, Lumpkin, and Hills (2010) admit that their model has room for improvement, demonstrating the complexity of entrepreneurial implementation. Like the theoretical literature on creativity and entrepreneurship, there seems to be little consensus about measuring important constructs such as the above success factors of entrepreneurship, opportunity recognition, building networks, and implementation. There are numerous articles on opportunity recognition, other articles that evaluate the network contributions to entrepreneurship, but more limited research that addresses implementation (Fayolle and Linan 2014).

We suspect that entrepreneurial implementation research suffers from the same domain specificity issues that have slowed or limited creativity research. Still, it appears that 
future research should identify implementation factors/actions that might cross domains, or at least apply to major industry such as health care. Implementation intention and commitment (Adam and Fayolle 2015) may be intervening variables that deserve further exploration. Alternatively, perhaps "grit," a combination of effort and perseverance needs to be adapted to an activity scale. Finally, and most importantly, models that bring actions together with the underlying constructs will help to move the discipline forward. Other authors have made starts in the area (e.g. Dyer, Gregersen, and Christensen 2008), but again, there is not consensus. Each article contributes a small bit of understanding to this complex and interesting phenomenon, and much work remains to be done.

\section{References}

Adam, A. F. \& Fayolle, A. (2015). Bridging the entrepreneurial intention=behavior gap: The role of commitment and implementation intention. International Journal of Entrepreneurship and Small Business, 25(1), 36-54.

Ahlin, B., Drnovšek, M., \& Hisrich, R. D. (2014). Exploring the moderating effects of absorptive capacity relationship between social networks and innovation. Journal for East European Management Studies, 19(2), 213-235.

Ahlin, B., Drnovšek, M., \& Hisrich, R. D. 2014. Entrepreneurs' creativity and firm innovation: the moderating role of entrepreneurial self-efficacy. Small Business Economics, 43, 101-117.

Amabile, T.M. (1996a). Creativity in context: Update to the social psychology of creativity. Boulder, CO: Westview

Amabile, T. M. (1996b). Creativity and Innovation in Organizations. Publication \#9-396239. Harvard Business School Press: Research note prepared for MBA class: Entrepreneurship, Creativity, and Organization.

Amabile, T. M (1983). The social psychology of creativity: A componential conceptualization. Journal of Personality and Social Psychology, 43, 357-376.

Anderson, A. R. (2000), Paradox in the periphery: an entrepreneurial reconception, Entrepreneurship and Regional Development, Vol 12, No 2, 91-110.

Anderson, A. R. and Starnawaska, M., (2008). Research Practices in Entrepreneurship: Problems of Definition, Description, and Meaning. Available from OpenAIR@RGU. [online]. Available from: http://openair.rgu.ac.uk. Accessed June 11, 2014.

Ardichvili, A., \& Cardozo, R. N. (2000). A model of the entrepreneurial opportunity recognition process, Journal of Enterprising Culture, 8(2) 103-119.

Ardichvili, A., Cardozo, R. N., \& Ray, S. (2003). A theory of entrepreneurial opportunity identification and development. Journal of Business Venturing, 18, 105-123. 
Baer, J. (2012) Domain Specificity and the Limts of Creativity Theory. Journal of Creative Behavior, 30, 183-187.

Baer, J. (1996) The effects of task-specific divergent-thinking training. Journal of Creative Behavior, 30, 183-187.

Baer, J. (1998) The case for domain specificity of creativity. Creativity Research Journal 11 (2), 173-177.

Barrett, H., Balloun, J. L. \& Weinstein, A. (2005) The impact of creativity on performance in nonprofits. International Journal of Nonprofit and Volunteer Sector Marketing, 10, 213-223.

Berglund, H. \& Wennberg, K. (2006). Creativity among entrepreneurship students: comparing engineering and business education. International Journal of Continuing Engineering Educationa and Lifelong Learning, 16(5), 366-379.

Bratnicka, K. \& Bratnicki, M. (2013), Linking two dimensions of organizational creativity to firm performance: the mediating role of corporate entrepreneurship and the moderating role of environment. Advances in Business-Related Scientific Research Journal, 4,(2), 153-163.

Bruyat, C., and Julien, P.A. (2005). Defining the field of research in entrepreneurship. Journal of Business Venturing, 16, 165-180.

Burt, R. S. (2000). The network structure of social capital. Research in Organizational Behavior, 22, 345-423.

Carland, J. W., Hoy .F., Boulton. W. R. \& Carland. J. C. (1984). Differentiating entrepreneurs from small business owners: A conceptualization. Academy of Management Review, 9(2),354-359.

Carson, D., Cromie, S., McGowan P. \& Hill, J. (1995). Marketing and Entrepreneurship in SMEs, An Innovative Approach, Prentice-Hall, Englewood Cliffs, NJ.

Corbett, A. C. (2005). Experiential learning within the process of opportunity identification and exploitation. 29(4), 473-491.

Covin, J. G., \& Slevin, D. P. (1991). A conceptual model of entrepreneurship as firm behavior. Entrepreneurship Theory and Practice, 16(1), 7-25.

Covin, J. G., and Slevin, D. P. (1989). Strategic management of small firms in hostile and benign environment. Strategic Management Journal, 10: 73-87.

Covin, J. G., \& Slevin, D. P. (1986). The development and testing of an organizationallevel entrepreneurship scale. Frontiers of Entrepreneurship Research, 626-639. 
Covin, J. G., \& Wales, W. J. (2011). Measurement of entrepreneurial orientation. Entrepreneurship Theory and Practice, 36(4) 626-639.

Crossan, M., Lane, H. W., \& White, R. E. (1999). An organizational learning framework: from intuition to institution. Academy of Management Review, 24(3), 522-537.

Davidsson, P. (2006). The types and contextual fit of entrepreneurial processes, in Burke, A. E., Modern Perspectives on Entrepreneurship, Senate Hall Academic Publishing.

Dayan, M., Zacca, R., and Di Benedetto, A. (2013). An exploratory study of entrepreneurial creativity: Its antecedents and mediators in the context of UAE firms. Creativity and Innovation Management, 22(3), 223-240.

Dimov, D. 2007a. From opportunity insight to opportunity intention: The importance of person-situation learning match. Entrepreneurship Theory and Practice, 31(4), 561-583.

Dimov, D. 2007b. Beyond the single-person, single-insight attribution in understanding entrepreneurial opportunities. Entrepreneurship Theory and Practice, 31(5), 713731.

Dyer, J. H., Gregersen, H. B. \& Christensen, C. (2008). Entrepreneur behaviors, opportunity recognition, and the origins of innovative ventures. Strategic Entrepreneurship Journal, 2, 417-338.

Eisenhardt, K. M. 1991. Better stories and better constructs: The case for rigor and comparative logic. Academy of Management Review, 16(3)), pp. 620-627

Eisenhardt, K. M. 1989. Building theories from case study research. Academy of Management Review, 14, 532-550.

Fillis, I., and McAuley, A. (2000). Modeling and measuring creativity at the interface. Journal of Marketing Theory and Practice, 8(2), 8-18.

Fillis, I., and Rentschler, R. (2005). Using creativity to achieve an entrepreneurial future for arts marketing. International Journal of Nonprofit and Voluntary Sector Marketing, 10, 275-287.

Fayolle, A. and Linan, F. 2014. The future of research on entrepreneurial intentions. Journal of Business Research, 67, 663-666.

Ford, C. M., Sharfman, M.P, \& Dean, J.W. (2008). Factors associated with creative decisions. Creativity and Innovation Management, 17(3) 171-185.

Gartner, W. B. (1989). 'Who is an Entrepreeur?' is the Wrong Question. Entrepreneurship Theory and Practice, (Summer), 47-67. 
Gielnik, M M., Frese, M., Graf, J. M., \& Kampschulte, A. (in press). Creativity in the opportunity identification process and the moderating effect of diversity of information. Journal of Business Venturing.

Gregoire, D. A., Shepherd, D. A., and Lambert, L. S. (2010). Measuring opportunityrecognition beliefs: Illustrating and validating an experimental approach. Organizational Research Methods, 13(1), 141-145.

Hamidi, D. Y., Wennberg, K. \& Berglund, H. (2008) Creativity in entrepreneurship education. Journal of Small Business and Enterprise Development, 15(2), 304320. https://doi.org/10.1108/14626000810871691

Hansen, D. J., Lumpkin, G. T. \& Hills, G. E. (2011). A multidimensional examination of a creativity-based opportunity recognition model, International Journal of Entrepreneurial Behaviour and Research, 17 (5), 515-533.

Hills, G. E., Shrader, R. C., \& Lumpkin, G. T. (1999). Opportunity recognition as a creative process. Frontiers of entrepreneurship research, 19(19), 216-227.

Hong, F. T. (2013). The role of pattern recognition in creative problem solving: A case study in search of new mathematics for biology. Progress in Biophysics and Molecular Biology, 113, 181-215.

Licuanan, B.F., Dailey, L. R. \& Mumford, M.D. (2007). Idea evaluation: Error in evaluating highly original ideas. The Journal of Creative Behavior, 41(1) 1-27.

Lumpkin, G. T., \& Dess, G. G. (1996). Clarifying the entrepreneurial orientation construct and linking it to performance. Academy of Management Review, 21(1), 135-172.

Lumpkin, G. T., Hills, G., and Schrader, R. (2004). Opportunity recognition. In H.P. Welsch (ed) Entrepreneurship: The way Ahead. New York: Routledge.

Matthews, J.H. (2007). Creativity and entrepreneurship: Potential partners or distant cousins?. In Chapman, Ross, Eds. Proceedings, Managing Our Intellectual and Social Capital: 21st ANZAM 2007 Conference, Sydney, Australia. 1-17.

Morris, M. H., Webb, J. W., Fu, J. \& Singbal, S. (2013). A competency-based perspective on entrepreneurship education: Conceptual and empirical insights. Journal of Small Business Mangement, 51(3), 352-369.

Mueller, S., Volery, T., \& von Siemens, B. (2012). What do entrepreneurs actually do? An observational study of entrepreneurs' everyday behavior in the start-up and growth stages. Entrepreneurship Theory and Practice, 36(5), 995-1017.

Napier, N. K., Vu, D. L. N., and Vuong, Q. H. (2012). It takes two to tango: Entrepreneurship and creativity in troubled times-Vietnam 2012. Sociology Study, 2,(9), 662-674. 
Nerkar, A., \& Shane, S. (2003). When do start-ups that exploit patented academic knowledge survive? International Journal of Industrial Organization, 21(9), 1391-1410.

Orhan, M., and Scott, D. (2001) Why women enter into entrepreneurship: An explanatory model. Women in Management Review, 16 (5), 232-247.

Perry-Smith, J. E., \& Mannucci, P.V. (2015). Social networks, creativity, and entrepreneurship. In C. E. Shalley, M. A. Hitt, \& J. Zhou (Eds.) The Oxford Handbook of Creativity, Innovation, and Entrepreneurship. New York: Oxford University Press.-

Phan, P., Zhou, J., \& Abrahamson, E. (2010). Creativity, innovation, and entrepreneurship in China. Management and Organization Review, 6(2), 175-194.

Pretorius, M. S., Millard, M., Kruger, M. E. (2005). Creativity, innovation and implementation: Management experience, venture size, life cycle stage, race and gender as moderators. South African Journal of Business Management, 36(4), 5568. https://repository.up.ac.za/handle/2263/2588 Accessed 6/25/2018.

Ritchie, Jane; Lewis, Jane \& Elam, Gillian (2003). Designing and selecting samples. In Jane Ritchie \& Jane Lewis (Eds.), Qualitative research practice. A guide for social science students and researchers (77-108) Thousand Oaks, CA: Sage.

Ronstadt, R. (2007) The Corridor Principle and Near Failure Syndrome: two generic concepts with practical value for entrepreneurs. Industry and Higher Education, 21(4), 247-252.

Rosly H.E., Junid, J., Lajin, N.F.M. and Rahim, H.L. (2015). The Relationship of Creativity and Technopreneurship Intention. International Academic Research Journal of Social Science 1(1): 8-15

Schmidt, J. J., Soper, J. C. \& Bernaciak J. (2013). Creativity in the entrepreneurship program: A survey of the directors of award winning programs. Journal of Entrepreneurship Education, 16, 31-42.

Shabbir, A. \& Di Gregorio, S. (1996) An examination of the relationship between women's personal goals and structural factors influencing their decision to start a business: The case of Pakistan. Journal of Business Venturing, 11(6), 507-529.

Shalley, C. E., \& Perry-Smith, J. E. (2008). The Emergence of team creative cognition: The role of diverse outside ties, sociocognitive network centrality, and team evolution," Strategic Entrepreneurship Journal 2: 23-41.

Sooy, J. (2011). "Unleashing management creativity," Franchising World, (March) 5859. 
Stevenson, H. H., \& Jarillo, J. C. (1990). A paradigm of entrepreneurship: Entrepreneurial management," Strategic Management Journal, 11 (Special Issue: Corporate Entreprensurship, Summer) 17-27.

Ward, T. B. (2004). Cognition, creativity, and entrepreneurship. Journal of Business Venturing, 19, 173-188.

Weinzimmer, L. G., Michel, E. J. \& Franczak, J. L. (2011). Creativity and a firm-level performance: The mediating effects of action orientation. Journal of Management Issues, 23, 62-82.

Westlund, H. (2011). Multidimensional entrepreneurship: theoretical considerations and Swedish empirics. Regional Science Policy \& Practice, 3(3), 199-218.

Yazan, B. (2015). Three approaches to case study methods in education: Yin, Merriam, and Stake. The Qualitative Report, 20(2), 134-152.

Yin, Robert K. (1994) Case Study Research. Design and Methods, Second edition. Thousand Oaks: Sage)

Zhang, Y. J. (2014). Correlation of regional innovation policy and private enterprise independent innovation capability. In 3rd International Conference on Science and Social Research (ICSSR 2014). Atlantis Press. 